\section{O grito das massas: retóricas e polêmicas}

The cry of the masses: rhetorics and polemics

Ana Cristina CARMELINO (UNIFESP)

anacriscarmelino@gmail.com

Luiz Antonio FERREIRA (PUC-SP) luizanferreira@terra.com.br

Recebido em: 15 de out. de 2018. Aceito em: 19 de dez. de 2018.
CARMELINO, Ana Cristina; FERREIRA Luiz Antonio. O grito das massas: retóricas e polêmicas. Entrepalavras Fortaleza, V. 9, n. 1, p. 209-230, janabr/2019.

Resumo: Este artigo pretende refletir sobre os principais argumentos que sustentaram a manifestação histórica e polêmica que, iniciada nas redes sociais, ganhou as ruas do Brasil e do mundo em 29 de setembro de 2018. Trata-se da campanha \#EleNão, cujo objetivo principal foi contestar a candidatura do presidenciável Jair Bolsonaro às eleições de 2018, no Brasil. A análise ancora-se nos pressupostos teóricos da Retórica e da Nova Retórica, especialmente a partir dos lugares retóricos, e considera como corpus de estudo cartazes que circularam durante o ato retórico e estão disponíveis na Internet. Entende-se a manifestação e a forma de fazê-la como uma prática social que busca conclamar direitos, testar ideais e explicitar acordos estabelecidos entre certos grupos.

Palavras-chave: Argumentação. Manifestação. \#EleNão. 
V. 9 (1)

209-230

jan-abr

2019

Abstract: This article aims to reflect about the main arguments that sustained the historical and controversial manifestation, started in social networks, that took over the streets of Brazil and the world on $29^{\text {th }}$ September, 2018. This is the \#EleNão campaign, that had as the main objective contest the presidential candidate Jair Bolsonaro's in the Brazil elections. The analysis is anchored in the theoretical assumptions of Rhetoric and New Rhetoric, especially from rhetorical places, and considers as corpus of study posters that circulated during the rhetorical act and are available on the Internet. It is understood the manifestation and the way of doing it as a social practice that seeks to call for rights, to test ideals and to explain agreements established in certain groups.

Keywords: Argumentation. Manifestation. \#EleNão.

\section{Retóricas e polêmicas: considerações iniciais}

As palavras revestem-se de inúmeros artifícios retóricos para encantarem, persuadirem, dissuadirem, convencerem e, assim, refletirem o saber, o querer e o fazer humanos. Em nossos dias, de modo ainda mais intenso do que sempre foi, as mídias sociais valem-se da palavra para disseminar, com velocidade espantosa, temas ligados à doxa que, com a mesma rapidez, infiltram-se no seio social e exortam as paixões eufóricas e disfóricas. Por consequência, o espaço público se move nervosamente por meio de discursos inflamados que conclamam deliberação e testam os ideais democráticos.

As questões sociais, então, adentram o universo discursivo denominado polêmico e se ressaltam sobremaneira a ponto de ferventar mentes e corações em torno de uma causa que se retorce nos contornos da controvérsia, atinge limites nem sempre racionais e o famoso acordo, tão necessário para a manutenção do convívio civilizado, se torna um obstáculo intrinsecamente ligado ao dissenso, à divisão profunda entre os seres a respeito de sentimentos, interesses, valores, convicções que radicalizam o pensar e o manifestar-se publicamente. A retórica, nesses casos, se ressalta sobremaneira, pois infiltra-se nos cenários políticos, religiosos, morais e éticos para comprovar a capacidade dos oradores e a reação do auditório. Ethos, pathos e logos se tornam veementes na tentativa de apregoarem "verdades", que surgem como resposta à profunda implicação de oradores e auditórios em torno de um tema proposto para ser polemizado e exortar paixões.

Nesse sentido, o discurso retórico se manifesta como a construção de uma argumentação que conduz o auditório numa direção, projeta um ponto de vista, busca adesão e, representa, de modo verossímil, uma determinada representação da realidade, pois o problema posto em foco é sempre uma construção discursiva sobre um contexto que se soma à interpretação de quem a vivencia. A polêmica que se instaura reside justamente na diversidade 
de opiniões entre um orador, colocado diante de uma questão mais ampla (que envolve fatores sociais, éticos, morais, de corporações, de instituições) e um auditório nem sempre dócil ou pronto para aceitar conceitos sobre questões filosóficas, públicas, políticas ou religiosas. Por isso, a lógica do razoável - o provável, o crível - assume lugar de destaque na argumentação e se subjuga apenas à autoridade do auditório, que, universal ou particular, dá a palavra final sobre o que se argumentou.

A discórdia é natural no convívio humano e, na opinião de Amossy (2017, p. 33), é "funcional nos grupos sociais em que as forças convergentes e divergentes estão sempre em interação" e, reforça, é a tensão do positivo e negativo que constitui o grupo como tal porque "um grupo totalmente harmonioso seria privado de estrutura e vitalidade". Para provar "vitalidade" e atuar no grupo, um orador precisa manifestar engenho earte para encontrar, na constituição do discurso, a índole das premissas necessárias para obter eficácia. Nesse sentido, a decisão de envolver-se num movimento dialéticodiscursivo requer esforço cognitivo e afetivo característico de uma antiga e fundamental divisão do sistema retórico: a inventio (quid dicat), ligada etimologicamente a "achar" (invenire) e "julgar" (iudicare).

No espaço da doxa, fundamentalmente não se discutem verdades e certezas, mas, sim, opiniões. Por isso, o movimento persuasivo é dialético, uma vez que permite a discussão de valores, de hierarquias, de preferências e, consubstanciado em discurso, consagra a própria dialética como objeto material da Retórica.

Para reforçar a intensidade da adesão do auditório, a relação de valores com outros valores e de hierarquias com outras da mesma natureza são muito necessárias, mas, como afirma Perelman (1997, p. 94), para realmente consolidála, o orador pode recorrer a premissas de ordem muito geral, qualificadas como lugares, comumente estudadas nos tratados consagrados ao raciocínio dialético. Nesse contexto, então, imbricam-se exercícios oratórios de natureza dialética, escolha acurada dos argumentos e rubricas (consideradas como lugares) que, na invenção (inventio), auxiliam a pertinência das provas no discurso.

Os lugares, então, constituem o foco analítico primordial dos textos aqui apresentados, colhidos na Internet, por ocasião do protesto histórico (e polêmico) ocorrido em 29 de setembro de 2018, no Brasil e no mundo, a partir da campanha hashtag \#EleNão, cujo objetivo principal era repudiar a candidatura do presidenciável Jair Bolsonaro às eleições de 2018, no país. A análise toma especificamente como corpus alguns dos cartazes que circularam especificamente ao longo do ato retórico e foram publicados em sites e redes sociais sob o registro de fotos. 
v. 9 (1)

209-230

jan-abr

2019

Nascido em Campinas, SP, em março de 1955, Jair Messias Bolsonaro ficou conhecido como militar da reserva e político brasileiro. Foi deputado federal de 1991 a 2018. Na sessão legislativa, foi titular da Comissão de Relações Exteriores e de Defesa Nacional, suplente da Comissão de Segurança Pública e Combate ao Crime Organizado e membro atuante da Comissão de Direitos Humanos e Minorias. Como afirma em seu site", busca lutar contra a "erotização infantil nas escolas e por um maior rigor disciplinar nesses estabelecimentos, pela redução da maioridade penal, pelo armamento do cidadão de bem e direito à legítima defesa, pela segurança jurídica na atuação policial e pelos valores cristãos".

O plano de governo de Bolsonaro - que tem como lema "Brasil acima de tudo. Deus acima de todos" e título "O Caminho da Prosperidade" - propõe uma gestão "decente, diferente de tudo aquilo que nos jogou em uma crise ética, moral e fiscal. Um governo sem toma lá-dá-cá, sem acordos espúrios" ${ }^{2}$. Na verdade, tanto a proposta de governo quanto os discursos inflamados do candidato (considerados por muitos como preconceituosos e autoritários) explicam, de certa forma, o ato público contrário ao presidenciável. Desse modo, uma pergunta fundamental, que move os oradores, é por que não é merecida a aprovação, pelo voto, do "ele"?

\section{Os lugares retóricos em questão}

Em texto que versa sobre a "Tópica de Perelman e OlbrechtsTyteca", Ferreira (2019, no prelo) observa que, para Aristóteles (2010), o lugar-comum é uma matriz semântica, uma espécie de molde discursivo que serve de espaço para a construção de argumentos conflitantes. Em retórica, essa é a função da Tópica, a disciplina que é parte da Dialética e que se propõe a investigar os lugares-comuns (tópoi - loci), vistos como fontes de argumentação. No Livro I dos Tópicos, Aristóteles (2010) anuncia um conceito muito preciso sobre a finalidade de seu Tratado:

descobrir um método que nos capacite a raciocinar, a partir de opiniões de aceitação geral, acerca de qualquer problema que se apresente diante de nós e nos habilite, na sustentação de um argumento, a nos esquivar da enunciação de qualquer coisa que o contrarie (ARISTÓTELES, Tópicos, Livro I, 2010, $\S 20-25)$.

\footnotetext{
${ }^{1}$ Disponível em: <https://www.bolsonaro.com.br/>. Acesso e: 10 out. 2018.

${ }^{2}$ Disponívelem:<http://flaviobolsonaro.com/PLANO_DE_GOVERNO_JAIR_BOLSONARO_2018. pdf $>$. Acesso em: 10 out. 2018.
} 
As opiniões comuns, aquelas geralmente aceitas e tomadas como "verdade", encontram, conforme Ferreira (2019, no prelo), lugar fundamental na base argumentativa e, por serem gerais e mais enraizadas no seio social, impõem reflexão, requerem investigação, exigem métodos de raciocínio sobre problemas, sobretudo quando as opiniões do auditório se fundamentam em crenças erísticas e contenciosas. O orador precisa levar em conta que a opinião possui espaços de ignorância, dúvida e certeza, que possui pelo menos dois lados dos quais um é mais aceitável do que o outro. Precisa considerar, também, que, ao atuar no plano da doxa, encontra-se no campo minado das representações da realidade e, por isso, sem garantias de estabelecer acordos se não justificar vigorosamente as premissas que sustentam sua argumentação, se não demonstrar, de modo claro e coerente, que são, pelo menos, apropriadas, exequíveis e necessárias no contexto retórico em que atua.

Modernamente, Perelman e Olbrechts-Tyteca (1996) retomam o tema e indicam claramente a base originária de suas considerações sobre os lugares na Nova Retórica: os estudos contidos na Tópica, de Aristóteles. Na segunda parte do Tratado de Argumentação (1996), - denominado "O Ponto de Partida da Argumentação", a partir do \$21 do primeiro capítulo, "O Acordo" - os autores remetem o leitor para a conceituação de lugares na retórica tradicional que, para os antigos, eram rubricas de imensa generalidade utilizadas para a classificação dos argumentos com o intuito de ajudar o orador no momento da inventio por meio do agrupamento do material necessário para a construção oratória. Por isso, até hoje, os lugares são conhecidos como "depósito de argumentos", "moradia dos argumentos" num processo comum de antropomorfização. Por falta de interesse dos lógicos pelo estudo dessas rubricas e em função do declínio da retórica, os lugares foram considerados uma banalidade e perderam o valor argumentativo. Para os autores do Tratado da argumentação, porém, é necessário considerá-los como um arsenal indispensável para quem pretende valer-se da persuasão no discurso. Para a Nova Retórica, lugares são "as premissas de ordem geral que permitem fundar valores e hierarquias e que Aristóteles estuda entre os lugares do acidente" (PERELMAN, OLBRECHTS-TYTECA, 1996, p. 93).

Aristóteles também estuda os tópicos na Retórica (Livro II, XIII e XXIV). Desse modo, então, Perelman e Olbrechts-Tyteca (1996) afirmam que pretendem a análise de argumentações concretas e, por opção teórica, põem de lado os demais lugares estudados por Aristóteles nos Tópicos: os lugares do gênero, do próprio, da definição e da identidade, para 
v. 9 (1)

209-230

jan-abr

2019

ressaltar apenas o lugar do acidente. Por acidente, Aristóteles entende "aquilo que não sendo nem definição, nem propriedade, nem gênero, ainda assim tem pertinência com a coisa (ARISTÓTELES, Tópicos, Livro I, V, 2010, 102b1, 5). Discutem, a seguir longamente sobre as práticas argumentativas relativas aos lugares, pois, segundo afirmam, não pretendem que os leitores tomem os lugares como contextos vazios. Conceituam, então, os dois lugares fundamentais: a quantidade e a qualidade e, a seguir, explicam o porquê de incluírem outros na lista dos lugares da Nova Retórica:

Poder-se-ia pensar em reduzir todos os lugares aos da quantidade ou da qualidade, ou mesmo em reduzir todos os lugares aos de uma única espécie - teremos a ocasião de tratar dessas tentativas -, mas parece-nos mais útil, dado o papel que representaram e continuam a representar como ponto de partida da argumentação, consagrar algumas exposições aos lugares da ordem, do existente, da essência e da pessoa. (PERELMAN; OLBRECHTS-TYTECA, 1996, p. 105).

Fica, assim, de forma resumida, o quadro de lugares propostos no Tratado, alicerçado sob a rubrica retórica que, como afirma Perelman em Retóricas, poderia ser considerada como a lógica do preferível (PERELMAN, 1997) e, assim, admitiria uma argumentação "pela qual somos convidados a aderir a uma opinião e não a outra" (p. 69):

Quadro 1 - Lugares-comuns

\begin{tabular}{|l|l|}
\hline \multicolumn{1}{|c|}{ Lugar } & \multicolumn{1}{c|}{ Descrição } \\
\hline Da quantidade & $\begin{array}{l}\text { É o que afirma que uma coisa é preferível a outra em razão } \\
\text { de dados quantitativos, que uma coisa é superior à outra por } \\
\text { ser mais proveitosa a um número maior de pessoas, ser mais } \\
\text { durável, mais útil. É um lugar que fundamenta anúncios } \\
\text { publicitários. }\end{array}$ \\
\hline Da qualidade & $\begin{array}{l}\text { É preferível aquilo que se sobrepõe ao outro por ser raro, } \\
\text { original, extraordinário. A opinião de determinado indivíduo é } \\
\text { melhor que a de todos. Trata-se de um argumento elitista. }\end{array}$ \\
\hline Da ordem & $\begin{array}{l}\text { É o que afirma a superioridade da causa sobre o efeito, } \\
\text { do anterior sobre o posterior. Glorifica-se o passado e } \\
\text { menospreza-se o presente. Também pertence a esse lugar o } \\
\text { argumento contrário. }\end{array}$ \\
\hline Do existente & $\begin{array}{l}\text { É o que declara superioridade daquilo que é sobre aquilo que } \\
\text { somente é possível, do prático sobre o teórico. }\end{array}$ \\
\hline Da essência & $\begin{array}{l}\text { É o que contempla os argumentos que mostram indivíduos que } \\
\text { representam um padrão, uma essência. }\end{array}$ \\
\hline Da pessoa & $\begin{array}{l}\text { É o que apela ao valor da pessoa, por sua importância; valoriza } \\
\text { o que é feito com cuidado, carinho, que requer esforço. }\end{array}$ \\
\hline
\end{tabular}

Fonte: Adaptado a partir do Tratado de Argumentação (1996). 
Neste trabalho, além, evidentemente, do lugar da qualidade e da quantidade (que resumem todos os outros), interessam-nos para a análise, sobretudo, os lugares da essência, do existente e da pessoa. Perelman e Olbrechts-Tyteca (1996) assim os explicam:

Entendemos por lugar da essência não a atitude metafísica que afirmaria a superioridade da essência sobre cada uma de suas encarnações - e que é fundamentada num lugar da ordem -, mas o fato de conceder um valor superior aos indivíduos enquanto representantes bem caracterizados dessa essência. Trata-se de uma comparação entre indivíduos concretos. (...) O que encarna melhor um padrão, uma essência, uma função, é valorizado por isso mesmo. (PERELMAN; OLBRECHTS-TYTECA, 1996, p. 106).

O lugar da essência, então, afirma a superioridade dos indivíduos que melhor representam a classe à qual pertencem, seres que são modelos bem caracterizados de uma essência, aqueles que encarnam melhor um padrão, uma função. Trata-se de destacar o excelente em uma comparação de um com vários da mesma espécie.

O lugar do existente, que se impõe enquanto vivência, enquanto atual, fundamenta-se tanto no lugar de quantidade (já que dá valor ao que é duradouro, ao estável, ao normal, ao que se impõe universalmente) quanto no lugar de qualidade (tendo em vista que dá valor ao que é único, existente, real).

Quanto aos lugares derivados do valor da pessoa, explicam os autores, estão vinculados à dignidade, ao mérito e à autonomia de um indivíduo. Não raro, o argumento incide sobre o mérito de um ato realizado por uma pessoa (ou grupo) para ressaltar a dignidade, a autonomia, a coragem, o senso de justiça. O orador estabelece hierarquias muitas vezes indispensáveis no ato retórico. Nesse lugar, o humano é ressaltado sobre todas as coisas. O lugar da pessoa assim como os outros mencionados, como veremos, sustentam argumentativamente os discursos veiculados no ato público e retórico que teve como lema \#EleNão.

\section{A campanha \#EleNão em contexto}

A hashtag \#EleNão constitui uma das expressões do movimento, em especial liderado por mulheres, de oposição à candidatura de Jair Bolsonaro à Presidência da República nas eleições de 2018 no Brasil. De forma a não explicitar nome, a fórmula é construída pelo pronome pessoal "ele" (que se refere à pessoa ou coisa que é tema do discurso) e a partícula negativa "não" (que funciona "como recusa absoluta a uma pergunta ou resposta"3).

$\overline{3}$ Ver significados do uso do advérbio "não" em Houaiss (2001). 
v. 9 (1)

209-230

jan-abr 2019

A expressão, que surgiu na página do Facebook "Mulheres Unidas Contra Bolsonaro" (MUCB) ${ }^{4}$, consiste numa tomada de posição (na qual "ele não" corresponde a "ele não tem meu voto, meu apoio") e passou a ser usada como mote para justificar ou explicar os motivos de tal posicionamento (por quais motivos o "ele" não teria o voto). Uma reação-resposta não apenas às declarações carregadas de preconceito feitas pelo candidato contra mulheres, negros, homossexuais e outras minorias, mas também ao plano de governo do presidenciável, que privilegia elites e revoga direitos dos trabalhadores ${ }^{5}$.

Para dar força à hashtag e apoiar o movimento das mulheres e LGBTs contra "o [candidato em questão]"6, Militão de Queiroz Filho, estudante de Letras na Universidade Estadual do Ceará, criou, em 13 de setembro, uma peça que se tornou o maior sucesso nas redes sociais. Feita em PhotoScape, a ilustração traz um letreiro que flutua em um céu estrelado, deixando um rastro de arco-íris (símbolo da bandeira LGBT) que sai da palavra "não"7.

\footnotetext{
4 Segundo Brum (2018), a expressão EleNão, que deu início a um protesto autônomo pelo Facebook: Mulheres Unidas Contra Bolsonaro, foi criada "por uma mulher negra, de origem periférica e anarquista". A página, que só aceita mulheres, atualmente tem quatro milhões de seguidoras.

5 NO BRASIL e no mundo, mulheres convocam "Todos contra Bolsonaro". Rede Brasil e no mundo, 28 set. 2018. Disponível em: <https://www.redebrasilatual.com.br/politica/2018/09/ no-brasil-e-no-mundo-mulheres-convocam-todos-contra-bolsonaro>. Acesso em: 10 out. 2018.

${ }^{6}$ ESTUDANTE cearense cria arte com a hashtag \#EleNão e viraliza. Diário do Nordeste, 18 set. 2018. Disponível em: <http://diariodonordeste.verdesmares.com.br/cadernos/nacional/ estudante-cearense-cria-arte-com-a-hashtag-elenao-e-viraliza-1.2001712>. Acesso em: 10 out. 2018.
}

${ }^{7}$ Moura (2018). 
Figura 1 - Foto do Instagram de Militão de Queiroz Filho

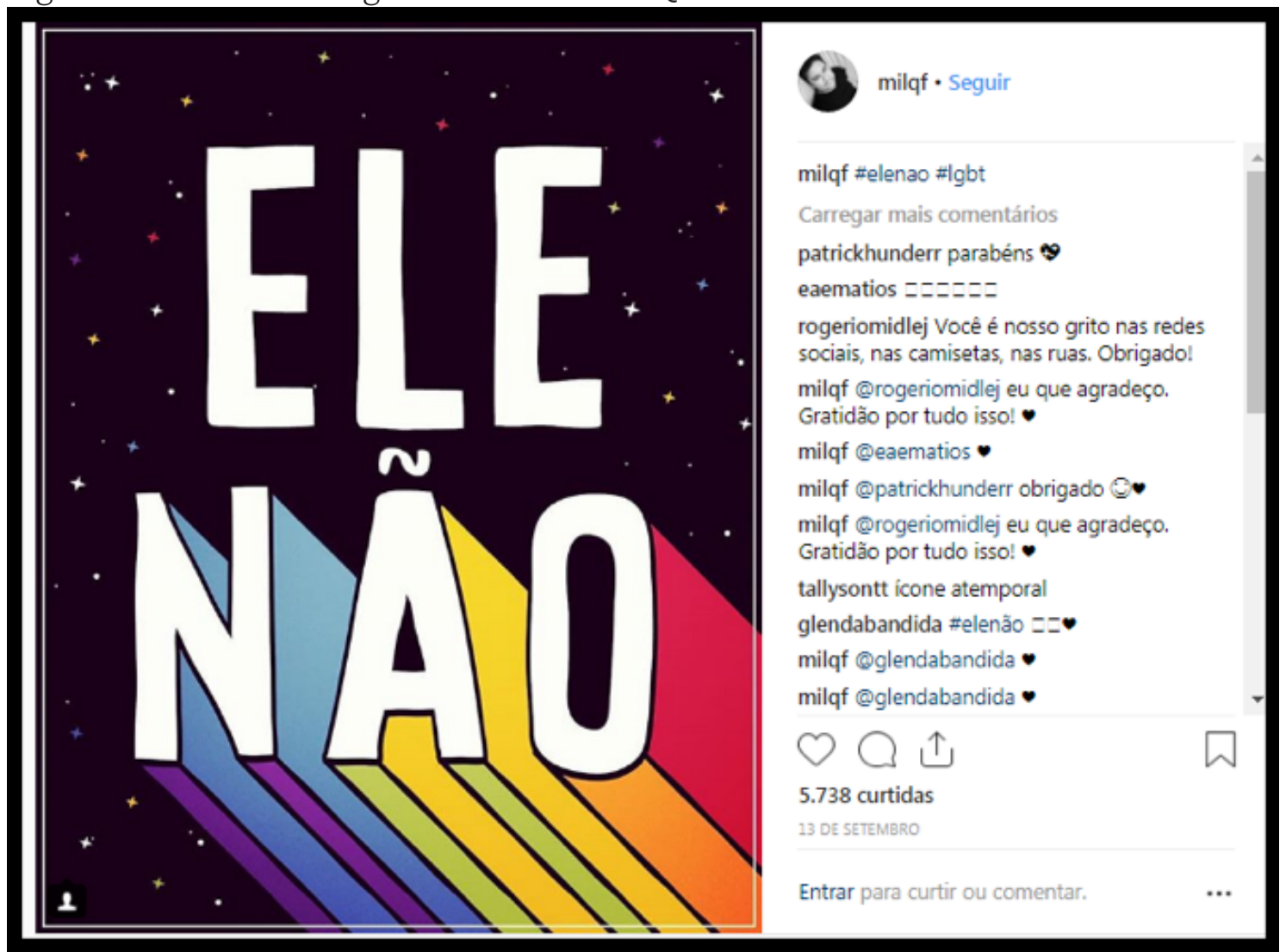

Fonte: <https://www.instagram.com/milqf/?utm_source=ig_embed>.

Replicada e compartilhada, inclusive por famosos (como atores, cantores, políticos) ${ }^{8}$, a postagem teve grande repercussão. Junto à viralização da hashtag, surgiram produtos (como camisetas) e outras artes com a expressão-chave (e/ou suas variações, caso de \#EleNunca e \#EleJamais).

A manifestação, iniciada nas redes sociais pelas mulheres, desencadeou não apenas a produção de uma série de vídeos feitos por pessoas em geral e artistas que explicitam seus motivos para não promover o deputado a presidente, mas também um ato público (ocorrido em 29 de setembro de 2018), o qual se transformou em um movimento mundial, apoiado por diferentes setores e movimentos sociais (Comunidade LGBT+, movimento negro, movimento estudantil, torcidas organizadas, artistas, cientistas, intelectuais e empresários entre outros), em rejeição à posição conservadora (e ameaçadora) representada por Jair Bolsonaro.

\footnotetext{
${ }^{8}$ Moura (2018) destaca que a criação de Queiroz foi replicada, sem que tivesse crédito, por "nomes como a candidata a vice-presidente Manuela D'Ávila (PC do B) - cujo post teve 100 mil likes -, a cantora Daniela Mercury (27 mil), a atriz Fernanda Lima (92 mil) e a cantora Pabllo Vittar (506 mil)". Artistas fora do país também aderiram ao movimento, replicando a tag, caso de Madonna, Cher, a atriz Ellen Page, o comediante Stephen Fry, as cantoras Dua Lipa e Nicole Scherzinger e o vocalista da banda Imagine Dragons, Dan Reynolds.
} 
V. 9 (1)

$209-230$

jan-abr

2019

O protesto, de acordo com a feminista Céli Regina Jardim Pinto9, foi a maior manifestação de mulheres na história do Brasil e um dos maiores movimentos contra um candidato, independentemente das mulheres. Pode-se dizer que a campanha \#EleNão tornou-se um significante repleto de significados, importante na luta política, uma vez que coloca em evidência a defesa pela democracia e pelos direitos humanos. É o que veremos nos cartazes analisados a seguir.

\section{\#EleNão por quê? Os lugares retóricos em seus devidos lugares}

O ato público ocorrido em 29 de setembro de 2018 consistiu num ato retórico. Todo ato retórico demanda, por natureza, artimanha por parte do orador para encontrar nas malhas do discurso o caráter das premissas necessárias para obter a eficácia. A decisão de envolverse num ato desse tipo, segundo destaca Ferreira (2019, no prelo), "requer esforço cognitivo e afetivo característico de uma antiga e fundamental divisão do sistema retórico: a invenção (inventio), ligada etimologicamente a "achar" (invenire) e "julgar" (iudicare)".

Mais ainda, o orador deve levar em conta não apenas o aspecto passional que envolve o auditório no instante da ação (actio) - tendo em vista que cada indivíduo hierarquiza valores de forma diferente -, mas também deve, ao proferir seu discurso na busca por persuadir, deixar claro na disposição (dispositio) que as causas que defende são justas, legais, apropriadas, honrosas, exequíveis e necessárias (cf. ARISTÓTELES, 2012).

Analisado, aqui, por meiodeum conjunto decartazes ${ }^{10}$ quesintetizam as justificativas da rejeição à candidatura de Jair Bolsonaro à presidência da República, os discursos, que se situam antes do primeiro turno das eleições, consistem em respostas para \#EleNão. Na busca de alterar opiniões, como veremos, os oradores pontuam seus dizeres pelos conhecimentos prováveis a fim de arrebatar mentes e corações em prol de uma causa. E é em função do auditório que desenvolvem sua argumentação, considerando que é por meio do plausível, principalmente dos lugares retóricos e da comparação antitética, que é possível construir o verossímil e angariar a adesão.

\footnotetext{
9 A feminista é autora do livro "Uma história do feminismo no Brasil" e professora do Departamento de História da Universidade Federal do Rio Grande do Sul (UFRGS), segundo Rossi, Carneiro e Gragnani (2018).

10 Por uma questão ética, achamos por bem recortar apenas os enunciados dos cartazes selecionados para a análise, desconsiderando os rostos das pessoas que os transportaram, uma forma de desidentificar os sujeitos envolvidos no ato público.
} 
Figura 2 - Conjunto de cartazes 1 - \#EleNão é tolerante

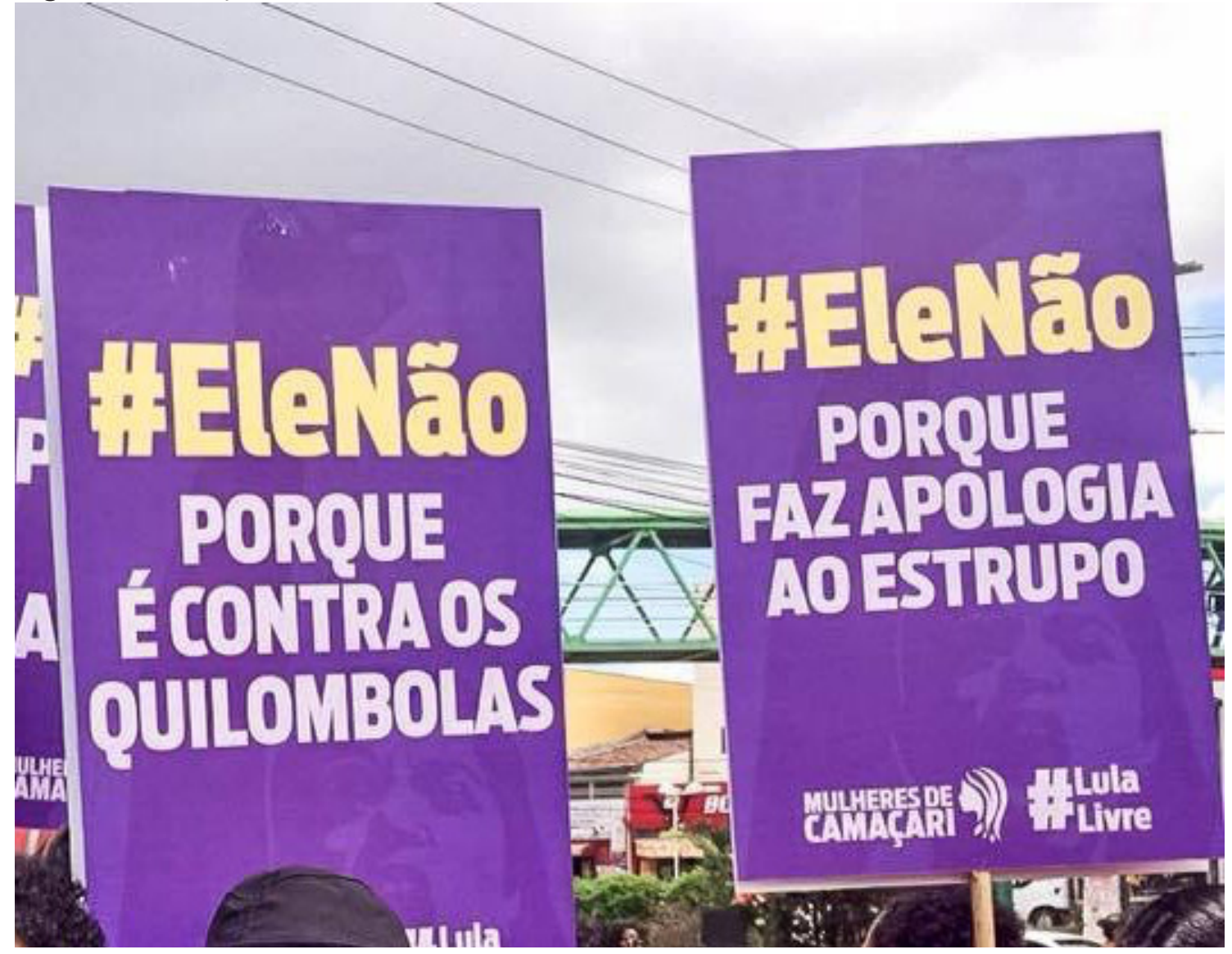

Fonte: <https://nossapolitica.net/2018/09/mulheres-bolsonaro-nas-ruas/>.

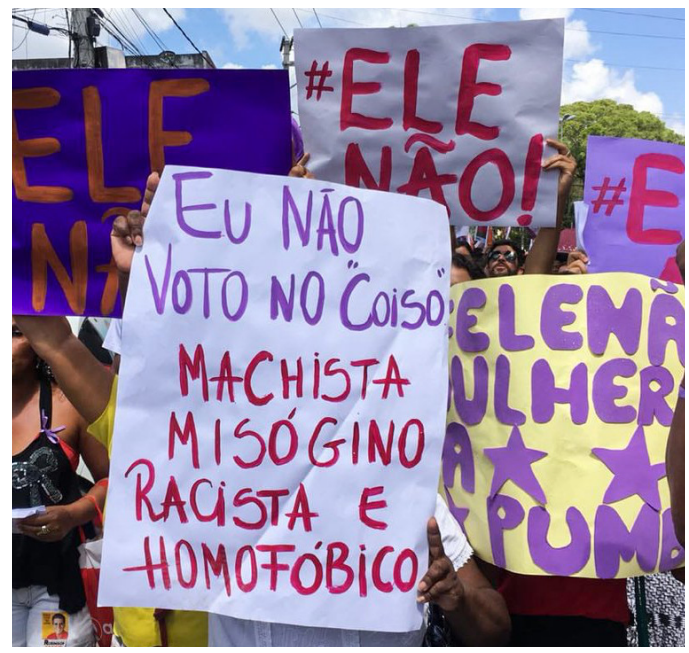

Fonte:

$<$ https://jornalggn.com.br/ noticia/elenao-pelo-brasil-e-mundoatos-contra-jair-bolsonaro-ao-vivo>

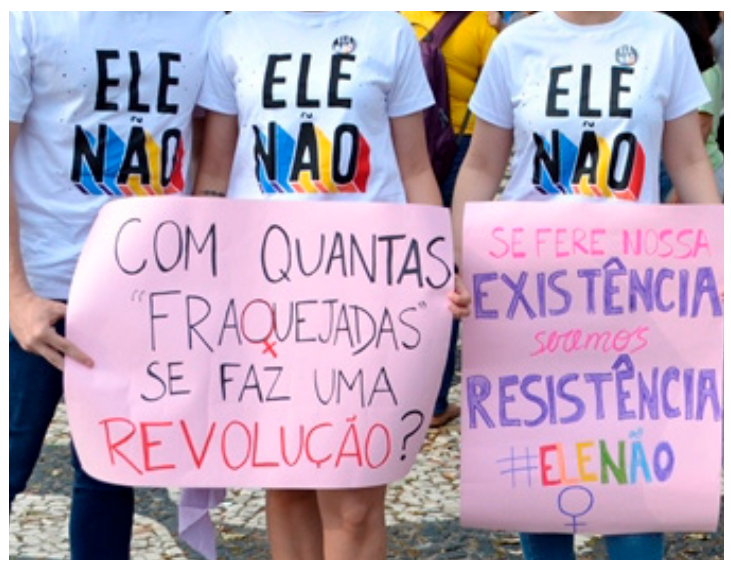

Fonte: <http://amazonasatual.com. br/wp-content/uploads/2018/09/Elenao-2.jpg>

Os enunciados dos cartazes acima advêm de oradores que se posicionam contrariamente a discursos considerados intolerantes, sejam os que são misóginos - "\#EleNão porque faz apologia ao estupro", "Eu não voto no coiso machista (...), "Com quantas fraquejadas se faz uma revolução" e "Se fere nossa existência, seremos resistência" - sejam 
v. 9 (1)

209-230

jan-abr

2019

os que defendem a violação dos direitos das minorias, caso de negros, índios, homossexuais - "\#EleNão porque é contra quilombolas" e "Eu não voto no coiso (...) racista e homofóbico".

O julgamento que coloca em questão a candidatura do "coiso", forma como é chamado nas redes sociais, tem origem em alguns dos discursos do presidenciável. Em palestra feita para a comunidade judaica (no Clube Hebraica), no Rio de Janeiro, em 3 de abril de 2017, Bolsonaro não apenas faz ataques de cunho racista contra negros, mas também dispara contra indígenas, mulheres, homossexuais e refugiados" ${ }^{11}$. O deputado, como destaca Brum (2018), afirmou "não estuprar uma deputada porque ela não mereceria por ser 'muito feia', assim como afirmou que as mulheres são produto de uma 'fraquejada' do macho no ato sexual. Além disso, disse que "negros de quilombos não servem nem para a procriação", que "é melhor ter um filho morto num acidente de trânsito do que namorando 'um bigodudo'", que "seus filhos jamais vão namorar uma negra porque 'são muito bem educados'", que "as mulheres têm que ganhar menos porque engravidam" ${ }^{12}$.

O discurso (ou a atitude) intolerante, portanto, é um dos motivos alegados para a recusa da candidatura de Jair Bolsonaro. A principal prova retórica que sustenta essa argumentação não é de ordem lógica. Os oradores consideram uma premissa de ordem geral que permite fundar valores, argumentam pelo lugar da pessoa. Esse argumento, como já dito, ressalta o humano sobre as demais coisas (PERELMAN; OLBRECHTS-TYTECA, 1996, p. 110), no caso, incide sobre o mérito de um ato realizado por um grupo de pessoas para salientar a dignidade, a autonomia, a coragem, o senso de justiça de todos (negros, índios, mulheres, homossexuais, camponeses).

\footnotetext{
${ }^{11}$ BOLSONARO: "Quilombola não serve nem para procriar". Congresso em foco, 5 abr. 2017. Disponível em: <https://congressoemfoco.uol.com.br/especial/noticias/bolsonaro-quilombolanao-serve-nem-para-procriar/>. Acesso em: 10 out. 2018.
}

${ }_{12}$ BRUM, E. Como resistir em tempos brutos. El País, 8 out. 2018. Disponível em: <https://brasil.elpais. com/brasil/2018/10/08/opinion/1539019640_653931.html>. Acesso em: 10 out. 2018. 
Figura 3 - Conjunto de cartazes 2 - \#EleNão é compatível com a democracia

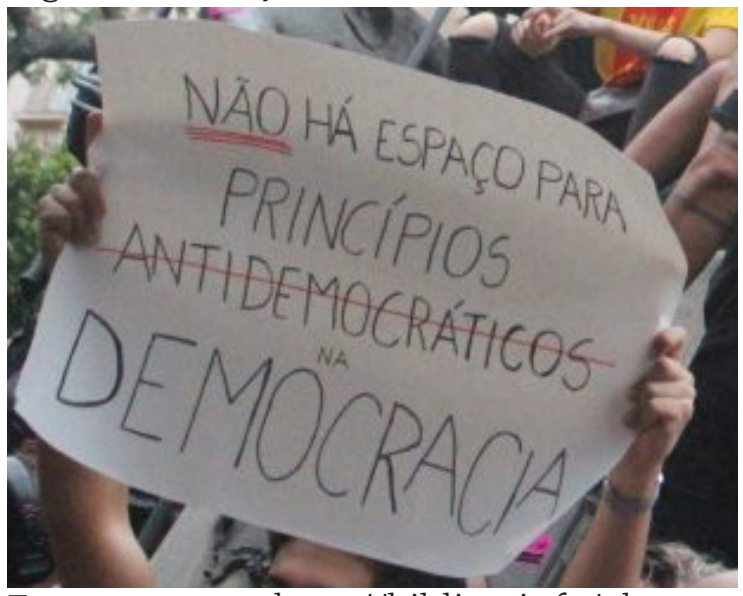

Fonte:

$<$ http://biblioo.info/elenaoreune-milhares-de-pessoas-no-rio-dejaneiro/>

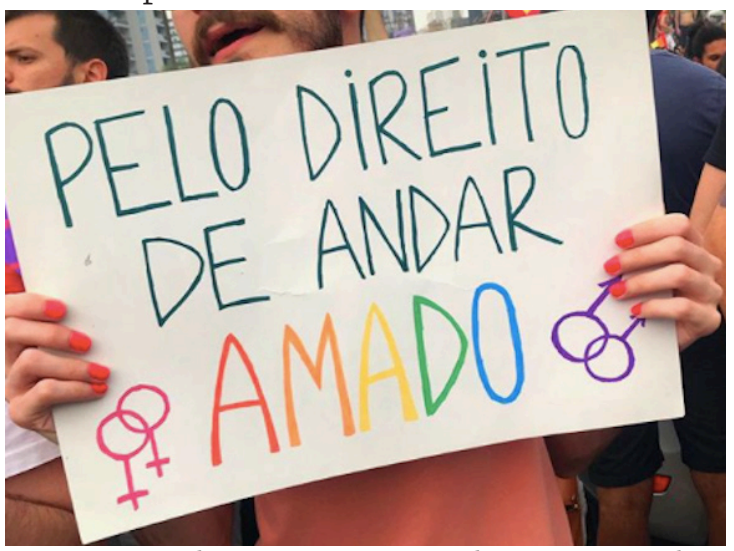

Fonte: <http://conexaoplaneta.com.br/ blog/contra-o-fascismo-no-brasilmilhares-de-mulheres-foram-as-ruasgritar-elenao-no-pais-e-no-mundo/ ele-nao-pelo-direito-de-andar-amadosp-foto-monica-nunes/>

Os enunciados desses dois cartazes advêm de oradores que repudiam discursos antidemocráticos. Em "Não há espaço para princípios antidemocráticos - Democracia", duas marcas de escrita explicitam o olhar crítico de quem segura o texto. A primeira é o advérbio "não", redigido de forma sublinhada. A segunda é o termo "antidemocráticos", que se apresenta riscado. Em ambos os casos, os recursos gráficos acentuam naturalmente as duas palavras.

O efeito prático - e intencional - disso é que o recurso ressignifica conteúdos de fala creditados a Bolsonaro, como se eles estivessem sendo "corrigidos" pelo manifestante. Ao invés de uma defesa explícita à violação dos direitos humanos, defende-se que uma democracia não coadune com propostas que firam essa forma de regime. Em outros termos: reitera-se a importância da democracia no país.

Essa linha de posicionamento sintetiza um histórico de declarações de Bolsonaro com flertes a um posicionamento mais autoritário. Um exemplo para o caso foi uma crítica feita ao pagamento do $13^{\circ}$ salário e do adicional de férias, que circulou nos dias anteriores à manifestação. A declaração foi creditada ao candidato a vice na chapa de Bolsonaro, general Hamilton Mourão ${ }^{13}$. Os benefícios são previstos na Constituição promulgada em 5 de outubro de 1988. Mexer em tais direitos seria, portanto, uma afronta à Constituição.

\footnotetext{
${ }^{13}$ Em palestra na Câmara de Dirigentes Lojistas de Uruguaiana (RS), em 25 de setembro de 2018, Mourão defendeu uma "implementação séria da reforma trabalhista", dizendo que o pagamento de $13^{\circ}$ salário e o pagamento do adicional de férias são "jabuticabas", só ocorrem no Brasil. (CAMPOS, 2018).
} 
v. 9 (1)

209-230

jan-abr

2019

O enunciado "Pelo direito de andar amado", grafado no outro cartaz, reforça outros direitos conquistados (como a lei que permite o relacionamento homoafetivo). Além da parte verbal, outro elemento se destaca: a pessoa que porta texto é do sexo masculino, porém usa batom e esmalte. Essa mescla, em homens, de acessórios historicamente associados a mulheres é uma maneira explícita de reforçar esse pensamento - ou esse direito, como registra o cartaz - no próprio corpo. A expressão "andar amado" remete também a um discurso de Bolsonaro, que defende à liberação do porte de arma para toda a população ("andar amado" < "andar armado"). Em carreata pelas ruas de Belém, em 5 de outubro de 2017, o presidenciável defendeu flexibilizar o porte de arma no Brasil: "Comigo não vai existir o politicamente correto. Vocês terão armas de fogo" 14 .

O discurso antidemocrático consiste em um dos argumentos para a rejeição de Bolsonaro. Sob essa ótica, ao considerar que a democracia seja um direito conquistado no Brasil, seria um risco perdêla. Num sistema democrático, prevê-se que todos os cidadãos tenham direito de se manifestar. O próprio voto, que elege os representantes do país, presidente entre eles, seria uma maneira de reforçar esses princípios. A linha de argumentação se ancora, no caso dos enunciados desses cartazes, em dois lugares retóricos, o lugar do existente, que dá preferência ao que já existe e se vincula "ao estável, ao habitual, ao normal" (PERELMAN; OLBRECHTS-TYTECA, 1996, p. 110), e o lugar da essência, que valoriza algo que representa um padrão tido como ideal. No caso em questão, é melhor manter o atual padrão de regime - a democracia - do que se arriscar por terrenos antidemocráticos ou autoritários.

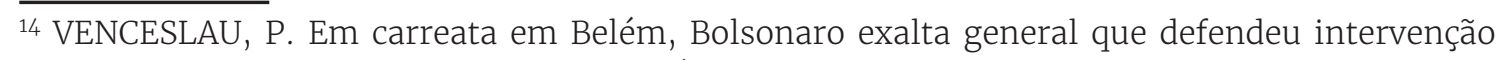
militar. Estadão, 5 out. 2017. Disponível em: <https://politica.estadao.com.br/noticias/ geral,em-carreata-em-belem-bolsonaro-exalta-general-que-defendeu-intervencaomilitar,70002029236>. Acesso em: 10 out. 2018. 
Figura 4 - Conjunto de cartazes 3 - \#EleNão porque faz apologia à ditadura

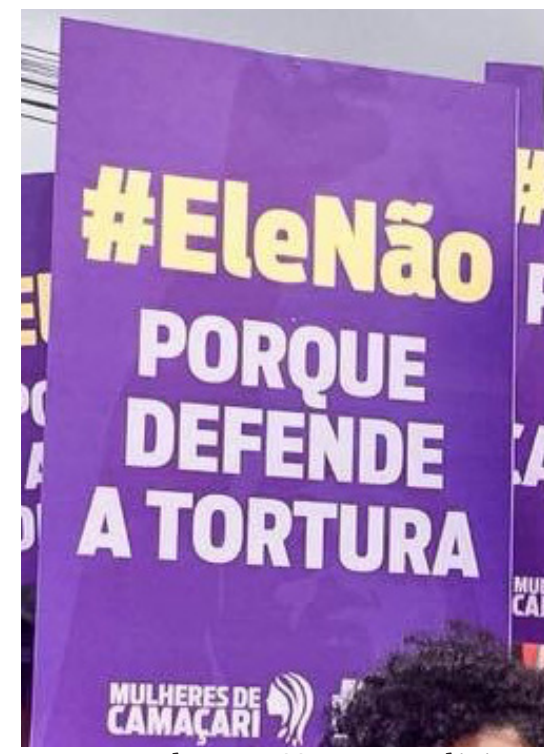

Fonte: <https://nossapolitica. net /2018/09/mulheres -

bolsonaro-nas-ruas/>

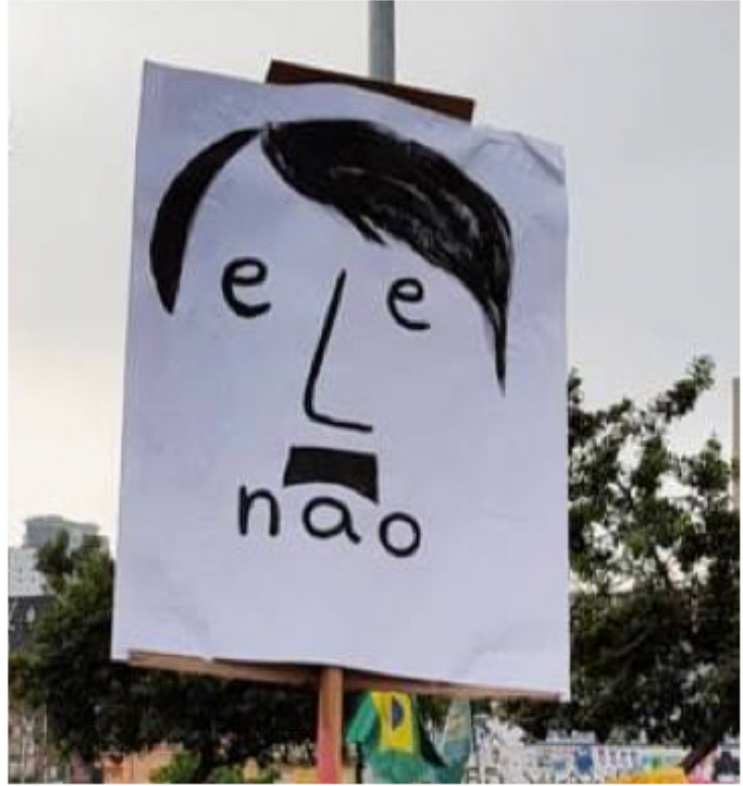

Fonte: <https://www.brasildefato.com. $\mathrm{br} / 2018 / 10 / 02 / \mathrm{mulheres}$-denunciamcandidato-fascista-em-20-cartazes/>

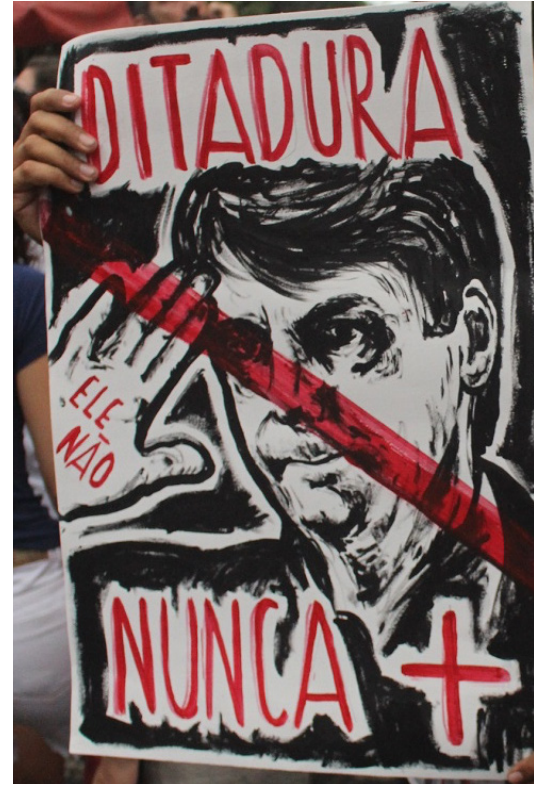

Fonte: <http://biblioo.info/ elenao-reune-milhares-depessoas-no-rio-de-janeiro/>

Os enunciados verbais e não verbais dos cartazes do conjunto 3 advêm de oradores que se mostram contrários a discursos que fazem apologia à ditadura militar. A argumentação, também nesse caso, é sustentada pelo lugar do existente, o qual, como o próprio nome diz, prefere o que existe, declara superioridade daquilo que é (ou está) sobre aquilo que é possível (pode vir a ser), ou seja, prefere-se o sistema de governo democrático (atual) e não o ditatorial, autoritário, como imputado à chapa de Bolsonaro. 
V. 9 (1)

$209-230$

jan-abr

2019

No que tange a essas considerações, Mourão, vice de Bolsonaro, defendeu a atuação das Forças Armadas em situação de caos no país e chamou de herói um dos torturadores do regime militar. Segundo o general, uma intervenção militar poderia ser adotada se o Poder Judiciário não solucionasse "o problema político", em referência aos casos de corrupção. Ele disse também, em outra ocasião, que o regime em que vivemos é frágil, "onde a moral e as virtudes foram enxovalhadas"15. Em entrevista ao programa Câmera Aberta, em 1999, Bolsonaro afirmou "que não acreditava que houvesse solução por meio da democracia e defendeu a morte de "30 mil", incluindo a de civis e a do então presidente Fernando Henrique Cardoso (PSDB)"

Falar bem da Ditadura Militar brasileira (1964-1985) era, pelo menos até então, algo bastante espinhoso para a população brasileira. O regime ficou marcado por atitudes autoritárias e de forte repressão a seus opositores. Prisões, torturas e mortes de pessoas contrárias ao sistema estavam entre as práticas adotadas, além de censura aos meios de comunicação de massa. Segundo o projeto Brasil: Nunca Mais (1986), que compilou casos de vítimas, os alvos preferenciais foram estudantes, sindicalistas, políticos, jornalistas e religiosos.

Os poderes autoatribuídos pelos militares se ancoraram no Ato Institucional número 5, também chamado de AI-5. Oficializada em 13 de dezembro de 1968, a medida permitia cassar os direitos políticos de opositores e proibia manifestações sobre temas políticos. Na leitura de Skidmore (1988), a proposta inicial era atacar as guerrilhas armadas. Controladas, o que ocorreu em 1972, seguiu-se uma ampliação dos alvos. Quaisquer pessoas potencialmente suspeitas passaram a se tornar possíveis vítimas dos militares. O discurso da ditadura, bem como os discursos autoritários imputados à chapa de Bolsonaro, como dito, contrariam o que representa o lugar de pessoa, que valoriza o humano.

Nos cartazes, a ditadura repudiada é representada de diferentes formas. Em "\#EleNão porque defende a tortura", a associação ao regime militar é feita por meio do vínculo com as agressões físicas efetuadas aos opositores. Na mensagem com o enunciado verbal "Ditadura nunca +", boa parte do sentido é criada por meio do desenho do candidato presidencial. Ele é representado fazendo continência - com o gesto de pôr a mão direita ao lado da cabeça. Na palma de sua mão, o autor da arte inseriu o slogan do "Ele não". Soma-se a isso o risco sobre ele, reforçando a negativa a ele.

\footnotetext{
15 VICE de Bolsonaro apoiou intervenção militar e chamou torturador de herói. UOL, 6 ago 2018. Disponível em: <https://www1.folha.uol.com.br/poder/2018/08/vice-de-bolsonaro-apoiouintervencao-militar-e-chamou-torturador-de-heroi.shtml>. Acesso em: 10 out. 2018.

${ }^{16}$ Bragon (2018).
} 
O estado de exceção é ampliado no terceiro cartaz. Neste, vincula-se o político a Adolf Hitler (1889-1945), representado na imagem, e ao regime nazista. Este foi marcado por princípios fascistas e antissemitistas, os quais levaram a Alemanha à Segunda Guerra Mundial (1939-1945). No caso em tela, os olhos do líder alemão servem para marcar duas vogais "e". O nariz faz as vezes do "l". Juntos, compõem o pronome "ele", complementado pelo "não", que aparece logo abaixo do marcante bigode de Hitler.

Nesse caso, pode-se dizer que a argumentação se ancora também no argumento pelo antimodelo, o qual, conforme Perelman e Olbrechts-Tyteca (1996), diz respeito àquilo ou àquele que se deve evitar. Para os autores, se a referência ao modelo deve ser feita quando uma conduta, um comportamento particular serve tanto para fundamentar/ ilustrar uma regra geral, quanto para estimular uma ação nela inspirada, a referência ao antimodelo permite afastar-se de certas condutas/comportamentos.

Figura 5 - Conjunto de cartazes 4 - \#EleNão é competente

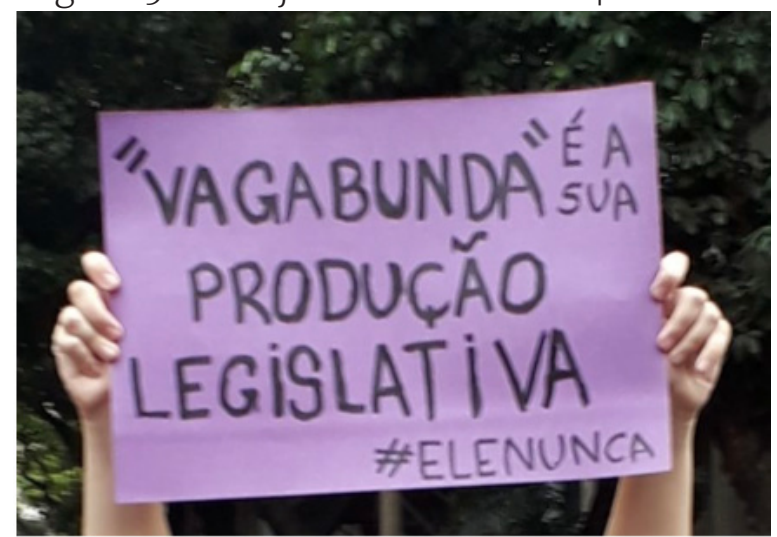

Fonte: <http://conexaoplaneta.com.br/wpcontent/uploads/2018/10/ele-nao-cabecavazia-mossoro-rn-foto-midia-ninja.png>

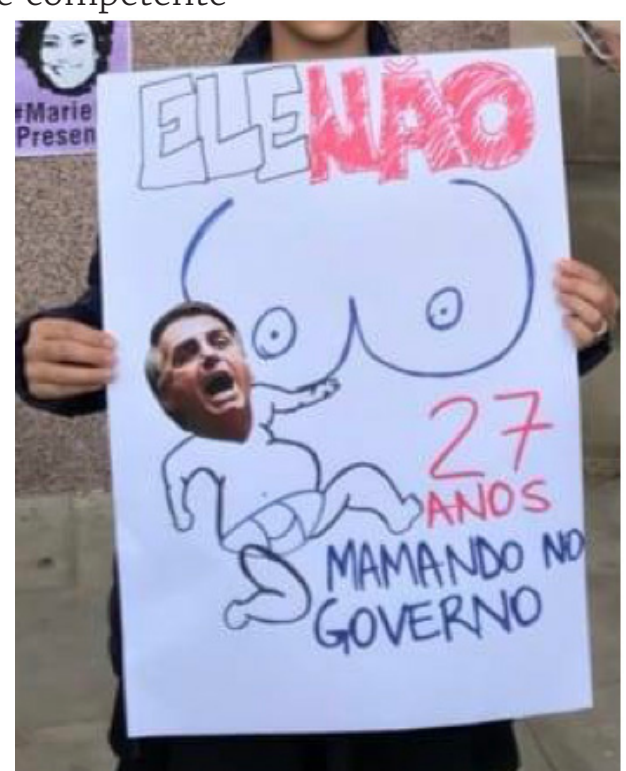

Fonte: <https://www.metropoles. com/brasil/politica-br/veja-oscartazes-mais-criativos-dasmanifestacoes-contra-bolsonaro>

Os enunciados dos cartazes acima advêm de oradores que rejeitam o presidenciável e levam em conta especialmente sua atuação durante sete mandatos (desde 1991) como deputado federal no Rio de Janeiro. O primeiro traz termo usado por Bolsonaro em discussão travada anos antes com a então deputada Maria do Rosário, quando a 
V. 9 (1)

$209-230$

jan-abr

2019

chamou de "vagabunda"17. Nos dizeres da manifestação, "vagabunda" seria a produção legislativa dele. No segundo texto, a sugestão é que o político teria "mamado nas tetas do governo", aproveitando-se dos benefícios salariais do cargo público.

Na biografia de Bolsonaro, disponibilizada em seu site, consta que:

Em seus mandatos parlamentares, destacou-se na luta contra a erotização infantil nas escolas e por um maior rigor disciplinar nesses estabelecimentos, pela redução da maioridade penal, pelo armamento do cidadão de bem e direito à legítima defesa, pela segurança jurídica na atuação policial e pelos valores cristãos. Foi idealizador do voto impresso, que certamente contribuirá para a realização de eleições mais confiáveis e passíveis de auditagem ${ }^{18}$.

Lindner (2017) ${ }^{19}$, partindo do levantamento feito pelo Estado/ Broadcast, comenta que durante três décadas na Câmara, "Bolsonaro apresentou 171 projetos de lei, de lei complementar, de decreto de legislativo e propostas de emenda à Constituição (PECs)", dentre os quais apenas dois viraram leis - uma proposta que estendia o benefício de isenção do Imposto sobre Produto Industrializado (IPI) para bens de informática e outra que autorizava o uso da chamada "pílula do câncer".

A argumentação nos cartazes desse grupo é sustentada especialmente pelo lugar da quantidade: as coisas valem mais (ou menos) por razões quantitativas (PERELMAN; OLBRECHTS-TYTECA, 1996). Ao destacarem a "produção legislativa como vagabunda" e "27 anos mamando nas tetas do governo", os enunciados buscam evidenciar que Bolsonaro produziu muito pouco. A quantidade funciona como argumento para ressaltar uma suposta incompetência.

Os cartazes, como podemos verificar, destacam um enfático NÃO a "ele". Por força do contexto retórico, o "ele" é reconhecido imediatamente pelo auditório. O NÃO explícito esconde-mostra a presença de um outro "ele", mais tolerante, mais competente, mais democrático e contrário à ditadura. Os cartazes, portanto, argumentam, por meio da comparação antitética e valem-se de um argumento quase-lógico, pois, os autores dos cartazes se valem dos argumentos de identidade e de definição

${ }^{17} \mathrm{O}$ vídeo que mostra a discussão travada entre Bolsonaro e a deputada federal pelo Rio Grande do Sul, Maria do Rosário Nunes, filiada ao Partido dos Trabalhadores está disponível em: $<$ https://www.youtube.com/watch?v=yRV98Im5zRs>. Acesso em: 10 out. 2018.

${ }^{18}$ Disponível em: <https://www.bolsonaro.com.br/>. Acesso em: 10 out. 2018.

${ }^{19}$ LINDNER, J. Bolsonaro aprova dois projetos em 26 anos de Congresso. O Estado de S.Paulo, 23 jul. 2017. Disponível em: <https://politica.estadao.com.br/noticias/geral,bolsonaro-aprovadois-projetos-em-26-anos-de-congresso,70001900653>. Acesso em: 10 out. 2018. 
para mostrar posicionamento político e ideológico. O "ele" dos cartazes amplia, por contraste, os valores do auditório e identifica identidades. Como afirmam Perelman e Olbrechts-Tyteca (1996, p. 238), "uma das técnicas essenciais da argumentação quase-lógica é a identificação dos diversos elementos que são objetos do discurso". Os cartazes, à sua maneira, praticam uma classificação do "ele" por meio da identificação parcial do elemento contestado e definem, condensadamente, elementos éticos e morais julgados fundamentais na concepção de um todo, ligado ao caráter e às posições políticas e ideológicas do candidato à presidência da República. O gênero retórico escolhido, o epidítico, louva pelo avesso a postura de Bolsonaro e reforça o lugar do valor da pessoa, para, também pelo avesso, exaltar princípios que se sedimentaram no discurso dominante sobre a importância da liberdade, do regime democrático e dos costumes considerados fundamentais, pelos oradores, para o bom convívio humano. Como todos os cartazes mostrados se baseiam em afirmações prévias do candidato, as falas expostas ganham efeitos de verdade e permitem manifestações consideradas justificadas para, justamente, valorizar a posição assumida pelos oradores. Justifica-se e argumenta-se, assim, o porquê do EleNão.

O discurso dos cartazes é, também, uma clara demonstração do discurso como ato do orador. As ligações entre orador e discurso representam um fator muito importante porque são acentuadas por meio da própria ação (actio). Perelman e Olbrechts-Tyteca (1996, p. 361), a esse respeito, afirmam que "mesmo as palavras alheias, reproduzidas pelo orador, mudam de significação, pois quem as repete sempre toma para com elas uma posição, de certa maneira nova, ainda que seja pelo grau de importância que lhes concede". Todos os cartazes, portanto, levam em conta as relações que existem entre a opinião que se tem do objeto do discurso epidítico e a maneira pela qual se julga o seu discurso. Por isso, o lugar primeiro é o da qualidade. Quando se pensa no número de cartazes diferenciados, todos criados a partir das falas do candidato, o lugar da quantidade também ganha destaque argumentativo.

Assim, a pessoa em foco concede um valor ao discurso e, no contexto da ação (actio), os oradores configuram o que Perelman e Olbrechts-Tyteca (1996) denominam "ethos oratório", aquele que se resume à impressão que o orador, por suas palavras, dá de si mesmo. Como o contexto em que se dá a ação (actio) é essencialmente político, os oradores assumem o papel de mentores, daqueles que aconselham, repreendem, mas, no fundo, por força do raciocínio dialético empreendido 
V. 9 (1)

$209-230$

jan-abr

2019

na ação, dirigem o pensamento do auditório para o que é considerado útil e necessário para a comunidade. Essa é a característica fundamental que o gênero judiciário assume no discurso que emana dos cartazes: o auditório, colocado como assembleia, diante de uma causa que aponta para o futuro, é levado a refletir sobre o útil, o conveniente e sobre o prejudicial e o nocivo. Os cartazes são mais do que um protesto público de natureza polêmica, pois aconselham o auditório a tomar uma posição por meio do voto.

\section{Considerações finais}

Existe, no universo da doxa, uma natural tensividade retórica, característica da dinâmica da comunicação social que acentua o que há de discordante no que diz respeito a conflitos de conceitos, choques semânticos, diferentes visões de mundo, diferenças ideológicas e crenças antagônicas. Os oradores, grupo composto pelos manifestantes que empunham cartazes, demonstram levar em conta o presente, o passado e o futuro para realçar as causas que defendem. O auditório, pois, assume um papel preponderante para a obtenção da eficácia retórica ao assumir o "fazer" pretendido: decidir, diante dos múltiplos fatores que envolvem o problema retórico em discussão, quais são os reais valores que devem ser apreciados, o que representaria o bom-senso comunitário e os interesses pessoais do grupo.

Os cartazes, ao polemizarem o futuro, refletem e promovem a intensidade das paixões, a capacidade de discernimento, na situação proposta, o que é conveniente, justo, legal, útil, nocivo, vergonhoso ou honrável para o futuro de toda uma nação. Os cartazes atingem diretamente os interesses e desejos do auditório. Exploram o lugar da qualidade, da essência, da existência, do valor da pessoa sobretudo para que, primordialmente, entendam a polissemia contida no advérbio "NÃO".

É prudente pensar que, em termos ideais, o auditório é capaz de analisar a força e a vulnerabilidade dos argumentos. O movimento em busca da compreensão do dito e do não dito, porém, é possível de ser captado em diferentes dimensões significativas, pois é, na essência, interpretativo. Os cartazes, considerados como ação retórica, indicam uma direção argumentativa e esforçam-se para atribuir ênfase discursiva a uma pergunta fundamental, que move os oradores: é merecida a aprovação, pelo voto, do "ele"? Para sedimentar o desejo de eficácia, destacam-se os lugares da qualidade, da quantidade, da essência, da existência e do valor da pessoa como um fundamento primeiro para todo o arcabouço argumentativo demonstrado. 


\section{Referências}

ARISTÓTELES. Órganon. 2. ed. Trad. Edson Bini. Bauru, SP: EDIPRO, 2010.

ARISTÓTELES. Retórica a Alexandre. Trad. Edson Bini. São Paulo: EDIPRO, 2012.

AMOSSY, R. Apologia da Polêmica. Trad. Rosalice Botelho e Wakim Souza Pinto. São Paulo: Contexto, 2017.

BOLSONARO: "Quilombola não serve nem para procriar". Congresso em foco, 5 abr. 2017. Disponível em: <https://congressoemfoco.uol. com.br/especial/noticias/bolsonaro-quilombola-nao-serve-nempara-procriar/>. Acesso em 10 out. 2018.

BRAGON, R. Nos anos 90, Bolsonaro defendeu novo golpe militar e guerra. UOL, 3 jun. 2018. Disponível em: <https://www1.folha.uol.com. br/poder/2018/06/nos-anos-90-bolsonaro-defendeu-novo-golpemilitar-e-guerra.shtml>. Acesso em: 10 out. 2018.

BRASIL: Nunca Mais. 15. ed. Rio de Janeiro: Vozes, 1986.

BRUM, E. Como resistir em tempos brutos. El País, 8 out. 2018. Disponivel em: <https://brasil.elpais.com/brasil/2018/10/08/ opinion/1539019640_653931.html>. Acesso em: 10 out. 2018.

CAMPOS, J. P. Vice de Bolsonaro critica $13^{\circ}$ salário e adicional de férias. Veja, 27 set. 2018. Disponível em: <https://veja.abril.com.br/economia/vice-debolsonaro-diz-ser-contra-pagamento-de-130-salario/>. Acesso em: 10 out. 2018.

ESTUDANTE cearense cria arte com a hashtag \#EleNão e viraliza. Diário do Nordeste, 18 set. 2018. Disponível em: <http://diariodonordeste. verdesmares.com.br/cadernos/nacional/estudante-cearense-criaarte-com-a-hashtag-elenao-e-viraliza-1.2001712>. Acesso em: 10 out. 2018.

FERREIRA, L. A. A tópica de Perelman e Olbrechts: reflexões sobre a nova retórica, 2019. (no prelo)

HOUAISS, A. Dicionário eletrônico Houaiss da língua portuguesa. Versão 1.0. Rio de Janeiro: Objetiva Ltda, 2001. CD-ROM.

LINDNER, J. Bolsonaro aprova dois projetos em 26 anos de Congresso. 0 Estado de S.Paulo, 23 jul. 2017. Disponível em: <https://politica.estadao. com.br/noticias/geral,bolsonaro-aprova-dois-projetos-em-26-anos-decongresso,70001900653>. Acesso em: 10 out. 2018.

MOURA, E. Estudante do interior do Ceará vê sua criação viralizar como símbolo da campanha \#EleNão. Folha de S.Paulo, Ilustrada, 28 set. 2018. Disponível em: <https://www1.folha.uol.com.br/ilustrada/2018/09/estudante-dointerior-do-ceara-ve-sua-criacao-viralizar-como-simbolo-da-campanhaelenao.shtml>. Acesso em: 10 out. 2018. 
v. 9 (1)

209-230

jan-abr 2019

NO BRASIL e no mundo, mulheres convocam "Todos contra Bolsonaro". Rede Brasil e no mundo, 28 set. 2018. Disponível em: <https://www.redebrasilatual. com.br/politica/2018/09/no-brasil-e-no-mundo-mulheres-convocamtodos-contra-bolsonaro>. Acesso em: 10 out. 2018.

PERELMAN, C. Retóricas. Trad. Maria Ermantina Galvão G. Pereira. São Paulo: Martins Fontes, 1997.

PERELMAN, C.; OLBRECHTS-TYTECA, L. Tratado da Argumentação. Trad. Maria Ermantina Galvão G. Pereira. São Paulo: Martins Fontes, 1996.

ROSSI, A.; CARNEIRO, J. D. C.; GRAGNANI J. \#EleNão: A manifestação histórica liderada por mulheres no Brasil. BBC News Brasil em São Paulo, Rio de Janeiro e Londres, 30 set. 2018. Disponível em: <https://www.bbc.com/portuguese/ brasil-45700013>. Acesso em: 10 out. 2018.

SKIDMORE, T. Brasil: de Castelo a Tancredo. 4. ed. Rio de Janeiro: Paz e Terra, 1988.

VENCESLAU, P. Em carreata em Belém, Bolsonaro exalta general que defendeu intervenção militar. Estadão, 5 out. 2017. Disponível em: <https://politica. estadao.com.br/noticias/geral,em-carreata-em-belem-bolsonaro-exaltageneral-que-defendeu-intervencao-militar,70002029236>. Acesso em: 10 out. 2018.

VICE de Bolsonaro apoiou intervenção militar e chamou torturador de herói. UOL, 6 ago 2018. Disponível em: <https://www1.folha.uol.com. br/poder/2018/08/vice-de-bolsonaro-apoiou-intervencao-militar-echamou-torturador-de-heroi.shtml>. Acesso em: 10 out. 2018. 